\title{
The Effectiveness of The Socialization Strategy of Taxation Regulation in Establishing Taxpayer's Objectives in Tax Rights and Obligations
}

\author{
Hetti Herawati \\ Department of Accounting \\ University of Sangga Buana YPKP \\ Bandung, Indonesia \\ herawati.hetti@yahoo.co.id
}

\author{
Senny Lusiana \\ Department of Accounting \\ University of Sangga Buana YPKP \\ Bandung, Indonesia \\ sennylusiana@ymail.com \\ Roni Tabroni \\ Department of Communication Sciences \\ University of Sangga Buana YPKP \\ Bandung, Indonesia \\ roni_tepas@yahoo.com
}

\begin{abstract}
To increase state revenues, it needs public awareness to perform its obligations to pay taxes. Currently, tax revenue in Indonesia is low. It takes a special effort to raise awareness of taxpayers, one of them by doing socialization. Socialization strategy conducted by the tax office is done by using mass media and face to face. This research uses analytical descriptive method. The purpose of this research is to create a systematic, factual and accurate description, the facts, nature, and relationship among various phenomena investigated. Research instrument used in the form of questionnaire. This research yields findings about Account Representative Service which have been considered good in doing service to taxpayer. In addition, the socialization strategy conducted by the tax office has been running well. So, with this positive result is expected to increase the awareness of the taxpayer.
\end{abstract}

Keywords: socialization; tax officials; mass media; taxpayers

\section{INTRODUCTION}

Tax sector, contributing about $70 \%$ of APBN revenues. Unfortunately, Indonesia's tax ratio is very low compared to other ASEAN countries. This condition becomes a big public relations for the government, which raises public awareness in fulfilling the rights and obligations of taxation. This condition must be assessed whether the lack of socialization from the fiscal party (the government) as a policy maker, or whether the socialization that is rolled out is not effective or appropriate [1]. The government is obliged to socialize to the taxpayer the contents of the tax law along with all complementary rules, so that taxpayers can exercise their taxation rights and obligations.

Fiscus as the party responsible for this problem must know the cause of the low public awareness in meeting tax obligations. Is it because of the lack of socialization from the tax authorities, or whether the socialization that is rolled out is less effective or improper, so citizen not understands the application process of the tax obligation itself [2].

In accordance with the Self Assessment System tax collection system, whereby the government (Fiscus) authorizes taxpayers to calculate, deposit and self-report the amount of tax payable, this shows the attitude of the tax authorities who actually hand over the whole process of taxation directly to the Mandatory Tax or give full trust to the Taxpayer.

This system gives consequences of responsibility to both parties, both taxpayers, and government (Fiscus). The government as the creator of the Tax Law has an obligation to socialize and provide understanding to the taxpayer the contents of the tax law along with all complementary rules, so that taxpayers can exercise their taxation rights and obligations. Taxpayers have an obligation to study, understand and implement all tax rules Apply in order to properly implement the taxation mechanism [2].

For the purpose of government in optimizing the tax revenue can be achieved, for it needs an effective socialization between the government (fiscus) and taxpayers by setting the right strategy.

Therefore, the purpose of this research is to analyze and to know the effectiveness of socialization of Tax Invitation Law and Regulation which has been implemented by the Tax Office (KANWIL and KPP), to analyze and know the effectiveness of communication strategy which has been done by AR in giving understanding to the taxpayer, and To analyze and know the effectiveness of the socialization of the tax law on the understanding of Taxpayers in implementing taxation rights and obligations [3].

The formatter will need to create these components, incorporating the applicable criteria that follow.

Corresponding author: Hetti Herawati 


\section{RESEARCH METHOD}

The method that writer use in this research is analytical descriptive method, that is a method in researching status of a group of human being, an object, a condition, a system, and one class of events at present. The purpose of descriptive research is to make description, picture, systematic, factual and accurate facts, traits, and relationships among the various phenomena under investigation. The author tries to analyze the data obtained from the results of research and compare it with existing theories, to then be analyzed its application in practice [4].

Table 1. Operationalization of Variables

\begin{tabular}{|c|c|c|c|c|}
\hline Variables & $\begin{array}{c}\text { Sub- } \\
\text { Variables }\end{array}$ & Indicators & $\begin{array}{c}\text { Indicator } \\
\text { scale }\end{array}$ & Instrument \\
\hline $\begin{array}{l}\text { Independent } \\
\text { Variable: } \\
\text { Effectiveness of } \\
\text { Socialization } \\
\text { Strategy (X) }\end{array}$ & $\begin{array}{l}\text { X1 : Mass } \\
\text { Media } \\
\text { X2 : Media } \\
\text { Face to Front }\end{array}$ & $\begin{array}{l}\text { Media Face to } \\
\text { Front } \\
\text { 1. Print Media } \\
\text { 2.Electronic } \\
\text { Media } \\
\text { 3.Media On Line } \\
\text { Communication } \\
\text { Account } \\
\text { 1. Representative } \\
\text { 2. In House } \\
\text { Training }\end{array}$ & Ordinal & Questioner \\
\hline $\begin{array}{l}\text { Variabel } \\
\text { Dependent } \\
\text { Variable: } \\
\text { Understanding } \\
\text { of Taxpayers } \\
\text { (Y) }\end{array}$ & $\begin{array}{l}\text { Taxpayer } \\
\text { Knowledge }\end{array}$ & $\begin{array}{l}\text { 1. Knowledge } \\
\text { 2. Awareness } \\
\text { 3. Ability }\end{array}$ & Ordinal & Questioner \\
\hline
\end{tabular}

To obtain the appropriate data, then this research using research instrument that is in the form of questionnaire. Questionnaires are then distributed to tax office employees.

In accordance with the research topic that has been determined "Effectiveness of Socialization Strategy of Taxation Regulation against Understanding Taxpayer in implementing taxation rights and obligations," then there are two variables that will be analyzed relationship, namely: independent variable independent variable and dependent variable.

The indicator serves as a clue as to whether the variable is working or not. If the indicator is well executed, then it is concluded that the variable is effective, but if the indicator is not executed properly, then the purpose of the variable is not reached. The variables and indicators and measurement scale used are summarized in TABLE I.

This study employs two methods in collecting data, which are interview and questionnaire. In addition, the researcher also gather data secunder from document study to support primer data.

The data analysis in this research will be done by using multiple regression analysis, correlation and coefficient of determination. However, since regression analysis requires that data have a scale of interval measurements, the ordinal results of the answer scores are converted to interval data through the method of successive interval [4] [5].

\section{RESULT AND DISCUSSION}

This research shows positive result related to Account Representative Activity. From the answers of respondents who reached $72 \%$ agreed with Account Representative Activities, it was found that Account Representative has done a very good communication strategy to the taxpayer.

One of the activities that is appreciated in the communication process is when Account Representative provides a fairly effective service as well as 500-200 tax rings. In addition, Account Representative also opens a tax and tax learning service that all aim to provide the best solution for all taxpayer issues [6] [7].

With such services, it is construed as one embodiment of one of the communication process between the tax officer and the taxpayer. So with the program, taxpayers can know about its obligations.

Based on the correlation analysis, this study shows that there is a correlation between the effectiveness of the strategy of socializing tax regulations with the understanding of the taxpayer. This correlation is more effective when the tax officer uses the mass media. While the correlation value between the effectiveness of the strategy of socializing tax regulations with the understanding of taxpayers through faceto-face media, including the most powerful. This means that activities that are face-to-face in socializing tax laws are considered more effective [8].

That is, communication strategy by using mass media do not beat communication directly in the form of face to face. Therefore, the tax officer does not leave a program that is met directly with the taxpayer. As well as above that learning tax, or tax consulting is still effective [9] [10].

Based on the results of effectiveness variables found that the strategy of socialization of tax regulations through the media face to face exactly shows the value of increase of 1 unit. While other variables are considered constant, then the dependent variable is the understanding of taxpayers will experience an increase.

Due to the socialization of tax laws through which performed by Account Representative is considered very good, then it is very influential on the understanding of taxpayers. Especially when the process of socialization of tax regulations was assisted with mass media and media face to face. When it involves these two media, the process of socialization of tax regulations is better accepted by the taxpayer [11] [12].

The study also found the existence of Account Representative Services and included mass media and face-toface media consistently. Even the activity becomes a simultaneous program. Thus, the tax officer hopes that the program can raise the awareness of the taxpayer, whose end is the tax revenue by the state [13] [14].

\section{CONCLUSION}

Communication strategy performed Representative Account has been very good, it is seen from the respondent's answer to indicator Account Representative has done 
communication strategy by stating $72 \%$ strongly agree and the remaining $28 \%$ agree.

The mass media has a positive and significant influence in socializing tax laws on the understanding of taxpayers.

Media face to face also apparently still have a positive and significant influence in socializing tax laws on the understanding of taxpayers.

The effectiveness of socialization strategy of taxation regulation simultaneously affects the understanding of taxpayers in implementing taxation rights and taxes.

\section{ACKNOWLEDGMENT}

This research was supported by Ministry of Research and Higher Education of Republic of Indonesia. We are also immensely grateful to this paper reviewer for their comments on an earlier version of the manuscript.

\section{REFERENCES}

[1] D. Binambuni, "Socialization PBB Influence on Taxpayer Complianc at Desa Karatung Kecamatan Nanusa Kabupaten Talaud”.(Sosialisasi PBB pengaruhnya terhadap kepatuhan wajib pajak di desa karatung kecamatan nanusa kabupaten talaud). Jurnal Emba, Vol 1 no 4, 2013.

[2] A.T. Setiyoningrum, J. Tinangon, "The Analysis of the Effect of Taxation Socialization, The Quality of Tax Service and Tax Sancions on the Taxpayer Compliance of Individuals in the Tax Office Manado".(Analisis pengaruh sosialisasi perpajakan, kualitas pelayanan fiskus dan sanksi perpajakan terhadap kepatuhan wajib pajak orang pribadi di kantor pelayanan pajak pratama manado). Jurnal Riset Akuntansi Going Concern. Vol 9, No 4, 2014.

[3] A.D. Prabowo, "The Effectiveness of Taxation Socialization on Tax Reporting Compliance Annual Taxpayer Individual in Service Office, Extension, and Taxation Consultation" (Efektivitas sosialisasi perpajakan terhadap kepatuhan pelaporan spt tahunan wajib pajak orang pribadi pada kantor pelayanan, penyuluhan, dan konsultasi perpajakan (KP2KP) tondano.. Jurnal Emba. Vol 3, no 1, 2013.

[4] Sugiyono, "The Methods of Quantitative, Qualitative, and R\&D Research". (Metode Penelitian Kuantitatif, Kualitatif dan R\&D)., Bandung, ALFABETA, 2016.

[5] R. Yuliawati, "The Influence of The Role of E-Filing and the Role of Account Representative to imaging Tax Authorities KP Pratama Par".(Pengaruh peran e-filing dan peran account representative (AR) terhadap pencitraan otoritas pajak KPP pratama pare”. prosiding.unipma. e-ISSN: 2337-9723, 2017.

[6] H. Cangara, "The Devising and Strategy of Communication".(Perencanaan dan Strategi Komunikasi). Jakarta, Rajawali Press, 2005.

[7] S. Mulyati, “ The Socialization Strategy to Increase An Exlucive Breastfeeding in Bengkulu City".(Strategi sosialisasi peningkatan pemberian ASI (PP-ASI) eksklusif di Kota Bengkulu”. xiii, 93 p., bibl., ills., $30 \mathrm{~cm}$. Universitas Gadjah Mada, 2004.

[8] N. Kusumaningtyas, " The Communication Strategy in Socializing the Transform of Coorporate Identity to the External Public."(Strategi komunikasi dalam mensosialisasikan perubahan corporate identity kepada publik eksternal (kasus the phoenix hotel yogyakarta). E-journal. E-journal.uajy.ac.id/id/eprint/3241. 19 july.2013.

[9] S. Rabilzani, "The Strategy of Public Relation in the Socialization of Occupational Health for the Employees of Turbine Generator Area Unitt III, PT. Menamas Mitra Energy in Desa Tanjung, Batu."(Strategi humas dalam sosialisasi keselamatan dan kesehatan kerja (K3) bagi karyawan area generator turbin gas unit iii pt.menamas mitra energi di desa tanjung batu kecamatan tenggarong seberang). ejournal Lmu Komunikasi. 1 (1): 2013, pp.1-8.
[10] C. E. Febriani, "The Strategy of Socialization Coorporate Culture at PT.GMF Aerosia Jakarta".(Strategi sosialisasi budaya perusahaan di PT. GMF aeroasia jakarta). Http://e-journal.uajy.ac.id/id/eprint/1209. 2013.

[11] L. Winerungan, "The Socialization of Taxation,Fiskus Service, and Tax Sanctions to the obedience Wpop in KPP Manado".'(Sosialisasi perpajakan, pelayanan fiskus dan sanksi perpajakan terhadap kepatuhan wpop di KPP manado dan KPP bitung).Jurnal Emba, Vol 1 No 3, 2013.

[12] M. Herryanto, A. Arianto Toly.“The Influence of Taxpayers Awareness , Socialization of Taxaction, and the Evaluation of income tax revenue in KPP Pratama Surabaya Sawahan".(Pengaruh Kesadaran Wajib Pajak, Kegiatan Sosialisasi Perpajakan, dan Pemeriksaan Pajak terhadap Penerimaan Pajak Penghasilan di KPP Pratama Surabaya Sawahan).. Studentjournal-petra. Vol 1, No 1, 2013.

[13] D. Widiastuti. "The Influence of Socialization, Motivation, and The Understanding of Taxpayer to the Obedience Taxpayer".(Pengaruh sosialisasi, motivasi, dan pemahaman wajib pajak terhadap kepatuhan wajib pajak (studi pada pengusaha kena pajak di kantor pelayanan pajak pratama malang utara). Jurnal Mahasiswa Perpajakan. Vol. 3 No $1,2014$.

[14] G. H Mead, "Mind, Self and Society: From a Standpoint of a Social Behaviorism, Ed". Charles Morris., Chicago, University of Chicago Press, pp. 1863-1931. 